\title{
The modernization of the Romanian standard language according to G. Ivănescu
}

\author{
Cătălin Nicolau ${ }^{\circledR \star}$ \\ Faculty of Letters, "Alexandru Ioan Cuza" University, Bd. Carol I 11, 700506 Iași, Romania
}

\begin{abstract}
Article info
History:

Key words:

written dialect

literary language

modernization

rhotacized text
\end{abstract}

Received April 15, 2020

Accepted May 6, 2020

Published June 10, 2020

\begin{abstract}
Our survey synthetically exposes G. Ivănescu's main ideas with respect to the notion of standard language in general and its modernization process in particular. This undertaking is a component of a larger research of Ivănescu's diachronic conception, which I have worked on for the last few years. As a result, the concept of standard language is approached here from a holistic perspective, that of the entire history of Romanian language, which, after all, it actually belongs to. This is the reason why some elements of the written language are related to the history of the spoken language and the principles of its research.

Our aim is pointing out the originality of this conception, which is divergent from that of the linguists in Bucharest, against a background characterized by a decreasing interest in in diachronic linguistics as compared to that in synchronic studies. Ivănescu succeeds in developing his original linguistic theory, relying on historical and socio-linguistic supporting arguments, which deepens, adds up to, and sometimes even contradicts the ideas of both his forerunners and his contemporaries.
\end{abstract}

\section{Introduction - the notion of standard language}

In this survey, we aim at exposing the way in which G. Ivănescu understood the modernization of the Romanian standard language. However, this process is complex and describing the researcher's vision upon it requires frequent references to other issues pertaining to the written language such as the very notion of standard language as well as the periodization of its history.

According to Ivănescu, the standard language represents the variety of any historical language that is used in written texts, irrespective of the specificity of their content. This vision is different from Ion Gheție's; the latter believes that one should distinguish between literary and non-literary texts (see Gheție, 1975, p. 65-66). According to him, the research should only focus on literary texts, i.e., those texts through which a cultural act is performed, which leaves the analysis of written language out of private documents (notes, letters, etc.)

The standard or common language is considered by Ivănescu a peak of the development of a historical language: "written languages ... represent the most important phase in the lives of languages. A language only reaches its highest level when it has developed a written variety" (Ivănescu, 1947, p. 2). Thus, creating a standard variety of a language demonstrates it getting to its highest stage of development and, at the same time, of its expressive capabilities.

As any dialect, the standard language has its own historical evolution, which, according to the Iassian scientist, has to be separated from that of the spoken varieties as the former is influenced by different factors. The reason is that the written language and the spoken dialects are different through their natures, each having its own separate evolution, based on specific principles. More precisely, while the development of spoken languages is influenced by three main factors (articulatory basis, psychologic basis, and social

`Email address: catalin_george2001@yahoo.com. 
structure), the evolution of the standard language only depends on the social element. Practically, both the beginnings and the development of the written language are explained by Ivănescu through the social structure and the cultural specificity of the linguistic community that use it. Another difference between spoken and written linguistic varieties is due to the fact that the former have an involuntary evolution, characterized by unintended innovations, whereas with standard languages an important role is played by will. A written variety that reaches a certain level of development ${ }^{1}$ is subject to great theoretical debates, which will direct its future evolution. Furthermore, the development of spoken varieties is due to a number of causes, while written languages are developed towards established goals ${ }^{2}$.

The spoken language is considered by Ivănescu a variety of a national language, historically developed, which is fundamentally different from its written variety. The great scholar argues that when speakers use spoken dialects, they are in what he calls a "natural state" (Ivănescu, [s.a.], p. 11), where the linguistic activity is more or less automatic, based on speakers' linguistic instincts. What this comes down to is the lack of reflective elaboration of the linguistic formulation as the oral expression is characterized by a high degree of spontaneity, which leaves speakers little time for selecting lexical units and grammatical structures. In this natural state the speakers are only influenced by their articulatory habits. The opposed condition is the "cultural state", which is specific to written communication. When in this latter state, the speaker can master his/ her dialectal inclinations and, thus, accept the rules of the variety which has been imposed as standard. Accepting and applying these norms are intentional and, thus, conscientious processes, which proves that the evolution of standard varieties depends on the will factor. The main difference between spoken and written varieties is that the phonetic evolution is reduced to a process of spontaneous creation in spoken dialects and to a process of conscientious and volitional imitation in the case of written languages.

In studying a standard language Ivănescu is also preoccupied with its sources or bases: on the one hand, the dialects of the studied language, from which spoken elements are taken and, on the other hand, other standard (foreign) languages, which become sources of loans. Thus, when it comes to our written language, one can talk about dialectal (Romanian) and foreign bases. Mention must be made that the influences of these bases are not constant throughout the entire existence of a standard language; their influence is variable as it depends on the dynamic role of the bourgeoisie in the economic, political, and cultural life of that specific people.

In Ivănescu's view, a standard language is not unitary along its entire existence; its unity only characterizes its maturity phase. Thus, in its initial stages, the standard language appears as a number of regional varieties, similar to the spoken dialects, and are called by the Iassian scholar written dialects (see infra). While reaching the mature phase, little by little, one of these written local varieties is imposed to the other areas as well and, thus, generalises its own system of rules. This process is a sophisticated one: it is carried out through the agreement of the scholars of the time and also involves a transfer of linguistic features among the existing written dialects.

\section{The old standard lnguage}

As far as the history of the Romanian written language is concerned, it is divided into two phases: the phase of the old and that of the modern standard language. The beginning of the former is connected by Ivănescu with the $15^{\text {th }}$ century, the researcher arguing that the rhotacized texts, which are placed by their filigrees in the $16^{\text {th }}$ century, are, actually, copies of some older texts, which must have been translated in the previous century. As regards the geographical area where the Romanian writing appeared, Ivănescu claims that the oldest Romanian texts (the rhotacized texts) were written in the Maramureș area. Their value consists in them exerting a strong influence on the writing in all the other Romanian areas, which

\footnotetext{
${ }^{1}$ This is what Ivănescu calls the modern phase of a standard language.

${ }^{2}$ According to Ivănescu, the purpose of the innovations brought to a written variety is adding extra-clarity in written communication.
} 
manifested through a series of Maramureș-like elements imposed on the old Romanian written language: "the language of the rhotacized texts, as a first form of the Romanian standard language, exerted a tremendous influence on the subsequent old Romanian written language and, by means of the latter, on the whole Romanian writing” (Ivănescu, 2000, p. 572). Thus, Ivănescu rejects the claim of such scholars as P.V. Haneș, Al. Rosetti, I. Bianu, or N. Cartojan that the Romanian writing has its origin in Coresi's language, him being considered by them the founder of our written language. The Iassian Professor shows that both Coresi's language and that of Neacşu's letter contain elements from the Maramureș area, such as io 'where' or corabii, forms that are likely not to have existed in the spoken language in Muntenia, which proves the influence of the rhotacized texts on the writing in Muntenia and, also, the existence of a written tradition in Maramureș.

As it has been suggested, the old written language is marked by lack of unity in the sense that it had regional differences, so it was represented by the so-called written dialects.

Written dialects are understood by Ivănescu as "regional varieties of the old Romanian standard language, characterized by phonetic, morphologic and even more lexical features" (Ivănescu, 1988, p. IX).

Thus, written dialects are diatopic varieties ${ }^{3}$ used in written texts in various geographical regions. The most differences are the lexical ones. Although this idea was not new, that is, other linguists had talked about them, even though under a different name, Ivănescu is the one who convincingly founded and illustrated this idea so that the theory of written dialects later attracted more and more adherents. Thus, the Iassian scholar identified the following written varieties for the old phase: the Crișean-Maramureșean dialect, which was rhotacised up to the $16^{\text {th }}$ century, the dialect in Banat, the dialect in Muntenia, and the Moldavian dialect, to which the dialect in Ardeal, used in the Southern part of the Mureș river, was also added.

\section{The transition period}

In the paper entitled Problemele capitale al vechii române literare [Essential Issues of the Old Standard Language], Ivănescu (1947) wrote that the old written language ended in the $19^{\text {th }}$ century. More precisely, he marked the decade 1820-1830 as the upper limit. He also mentioned that the end of the old written language was due to the beginning of the modern standard language, which he believed to be around 1780, when the Romania modern culture began. In Istoria limbii române [The History of the Romanian Language], Ivănescu's opinion appears slightly changed: the beginning of the modern written language is delayed half a century. Here he claims that in the interval 1780-1830, "a lot of remnants of the past" still persist on the cultural plane (Ivănescu, 2000, p. 630), while the modern culture becomes dominant starting with 1820-1830, when new authors start writing and new men of culture and politics become actively involved, especially in Moldavia and Muntenia, all of them showing a modern spirit. So, the years 1780 and 1830 border a transition period, which represented a first stage of modernization of the Romanian standard language. These years are no longer understood as punctual limits of the old and modern written languages; they mark the boundaries of a transition phase, during which the two languages are used in parallel ${ }^{4}$. By 1830, the old written language is still predominant; between 1830 and 1880 the modern written language starts to manifest and is finally imposed. Thus, the year 1780 does not

\footnotetext{
${ }^{3}$ In Coseriu (2000) the author distinguishes several types of linguistic varieties: diatopic (or territorial), diastratic (depending on the social stratum that the speaker belongs to), and diaphasic (with reference to linguistic styles).

${ }^{4}$ Ivănescu's more recent opinion, which introduces the period of transition from the old to the modern written language seems to us closer to E. Coseriu's theory of linguistic change. Unlike Saussure (1998, p. 113), where getting from the old to the new linguistic fact was understood (or, at least, this is what was suggested) as "sudden", instantaneous (due to the change being seen just as a result), Coseriu claimed that there was a period of co-existence of the two language facts, i.e., of the two being used in parallel (the change is seen as a process). See Coseriu (1977).
} 
mark the sudden beginning of the modern standard language; instead, it signals "a new phase of the old written language characterized by its sensitive modernization“" (Ivănescu, 2000, p. 632). Ivănescu was led to this new view by the linguistic facts that he had studied meanwhile.

In this period, one can distinguish two "styles" of the written language: a "religious style", i.e., a variety used in religious texts, and a "lay style" or a "style of lay literature" (Ivănescu, 2000, p. 628). These two varieties of the standard language start to take shape in the second half of the $18^{\text {th }}$ century as earlier the religious texts and the lay ones (artistic literature, official documents) had been rendered in roughly the same variety. The lay style is open to the phonetic and lexical influences of spoken dialects especially in the late $18^{\text {th }}$ century, when artistic literature (I. Budai-Deleanu, C. Conachi, Iancu Văcărescu) starts to develop, while the religious language is maintained almost unchanged, having a Southern aspect. So, in the $18^{\text {th }}$ century, the written language gets significantly close to the spoken dialect and the present-day standard language by means of the artistic works. The written language used until then, which had been established mostly through religious texts, remained in use by virtue of a literary tradition up to mid- $19^{\text {th }}$ century, when it is partially modernized, too.

A new kind of written language is used now, which continues the lay language in the previous period and which is close our present-day language. This new language is characterized by numerous neologisms, but what distinguishes them from our language today is their origin: the neologisms loaned in this period are of eastern (Greek, Russian, Turkish) origin in the Principalities and eastern-German (German, Latin, Hungarian) in Transylvania. Its phonetic and morphologic aspect "has an old character, although the content it conveys is new", i.e., it expresses new ideas through old linguistic means: some writers still use $-u$ after the final consonant, the imperfect forms ei cinta, ei vedea, the singular compound perfect au facut, words such as a oblici 'find out', predislovie 'preface', set phrases such as mai virtos 'especially', etc. As far as the scientific and philosophic terminologies are concerned, most terms are not neologisms (direct loans), but calques. Nearly all of them start to be replaced now with neologisms of Latin or Romance origin.

The lexical changes taking place now were imposed by the bourgeoisie, through its intellectuals. They also imposed phonetic and morphologic changes: practically, certain features of the language spoken by the bourgeoisie were imposed as norms of the written language as the language used by this category was closer to the spoken language than the written variety was.

A process taking place in all written dialects in the transition period is the adoption of Southern features, i.e., linguistic elements from Muntenia. In the regions of Transylvania, northern of Mureș and Banat, there is this tendency of replacing $\breve{g}$ with $\check{z}$ : leje, dejet, jurat, jurămînt, a înțeleaje, Mărjinime, Jioagiu, josu, jupinu, etc. We also identify here a transfer of features from the spoken dialects to the written language. The Southern influence in Transylvania is also manifested on the lexical level, whereby a series of terms of Turkish origin that are loaned in the $18^{\text {th }}$ century: leafa , scopos, etc.

The causes that underlay this Southern influence process are multiple: the decadence of the Transylvanian culture in the context of the Austrians' oppression in the name of Catholicism, the rise of the bourgeoisie, who did not know very well the writing tradition up to that time and, consequently, used numerous spoken elements in writing. Ivănescu believes that most Southern religious typed texts had contributed to this. According to him, the Southern texts had significant prestige to the Transylvanians especially since the Catholic oppression and the hard-living conditions did not allow for typing religious books in Ardeal; instead, books typed in Muntenia had to be used here, particularly during the ages of Constantin Brâncoveanu and Antim Ivireanu.

Another reason for the written language in Transylvania, Banat, Crișana, and Maramureș getting close to the one in Muntenia is attributed by Ivănescu to the fact that the spoken varieties in these regions, due to their phonetic evolutions, no longer functioned as bases for the written conventions, which had caused them to appear as dialectal in relation to the older written language (in Ardeal and some other areas). Thus, Transylvanians came to regard as standard what they had used neither in writing nor in oral speech up to that point, but the written language in Muntenia, which now they had the chance to become familiar with. They noticed that what they had been using in writing was closer to the conventions in 
Muntenia than their spoken dialect, which was characterized, among other things, by palatalized labial consonants. Furthermore, the written dialect in Muntenia was also used in the Southern Ardeal, which made the Northern Transylvanians identify the written standard in Muntenia with the one in Ardeal.

Changes of the written norms towards the ones in Muntenia also take place in Moldavia in the mid- $18^{\text {th }}$ century. The elements, characteristic of the old written tradition of Maramures,, are now replaced with such linguistic forms as: acum, aşa, curînd, țările, țării, șese, lege, etc. The affricates $\breve{g}$ and $d, d$ are, nevertheless, still maintained in words like ğoc and dic. In Moldavia, there is also an influence of the spoken local variety on the written language. The transfer of the spoken features to the written language did not occurred directly, but through some phonetic hypercorrect forms: osinda 'sentence', seu 'his' (possesive), trimețind, pirire, pirit, omorit, etc. This influence of the spoken forms on the written language, which is also typical of Muntenia as well, is due to the presence of the bourgeoisie, whose representatives, who were learned people, practiced a rather negligent kind of writing containing a series of elements pertaining to the spoken dialect. These are the causes considered by Ivănescu responsible for the written language getting contaminated by the oral tradition.

This is the time when the idea that the written language is like the dialect of Muntenia takes shape. According to Ivănescu, this fact, too, is owing to the rise of the bourgeoisie. As this category found its origin among ordinary people, its representatives used palatilized labials (in both Moldavia and Ardeal) and, thus, identified their speech with palatalized labial consonants as dialectal, while the variety with intact labials was considered standard, i.e., the one in Muntenia. This is why Ivănescu believs that the palatalization of labial consonants played an important role in the crystalization of the belief regarding the dialect in Muntenia as identical or, at least, similar to the written standard (Ivănescu, 1946-1947, p. 3839). Palatalization was not the only feature that caused the varieties in Transylvania and Moldavia to be felt as dialectal; there were some other elements as well: the palatalization or the affrication of consonants $/ \mathrm{t} /$ and $/ \mathrm{d} /$, when followed by palatal vowels, the confusion of consonants $/ \mathfrak{t} /$ and $/ \dot{d} /$ with $/ \mathrm{k}^{\prime} /$ and $/ \mathrm{g} /$, the closing of final /ă/ and /e/ to / $/$ / and /i/.

The main factor that led to this new linguistic intuition (of the dialect in Muntenia as a written standard for all Romanians) was, thus, the rise of the people from the lower social classes. The new conscience manifested at first through some phonetic standardizations, the written dialects keeping their individualities, broadly speaking. Around 1860, this self-awareness was augmented by other factors as well: the most developed Romanian-speaking bourgeoisie was the one in Muntenia and the capital of the new Romanian state was established at Bucharest. This idea of the dialect in Muntenia as the basis of the Romanian standard language has remained in the minds of both learned and ordinary people up to this very day, when it is still considered that obeying the rules of the standard language means talking as in Muntenia, even though this implies also using some elements specific to the southern dialect.

The transitional character of the standard language between 1780 and 1830 is due to the emergence of some signs of modernity. One of them pertains to the presence of neologisms, that were necessary for designating the new contents. With respect to this matter Ivănescu believes that "the nature of a written language lies in its expressing cultural ideas, so it depends on the nature of its vocabulary, which contains the necessary neologisms" (Ivănescu, 2000, p. 633), that is, the essence of a standard language lies in its capacity of conveying cultural contents. The process of adopting neologisms was just beginning, as what had been borrowed up to that time was not enough, while the terms introduced by some writers had not yet imposed. Moreover, the new lexical items still had their initial form in their original languages, since they were not adapted phonetically and morphologically to the Romanian language. Sometimes, the language "was still clumsy and imprecise" (Ivănescu, 2000, p. 633), in the sense that a tradition of using the new words had not been created yet.

In this period there were a great deal of attempts at turning the Romanian standard language into a true unique language of culture. These preoccupations had existed since the $17^{\text {th }}$ century, so that the attempts at modernization of the time continued the earlier ones. Ivănescu believes that the entire period of the old language and literature starting in the $17^{\text {th }}$ century should rightfully be considered modern. He 
refers to "the Romanian humanism of the old age" (Ivănescu, 2000, p. 633), acknowledging the duality of Romanian language and literature. According to the Iassian scholar, talking about an old Romanian culture as opposed to the modern one would be improper; instead, it would be better, he argues, for us to identify the old and the modern aspects of the Romanian culture: "a too clear-cut distinction between the old culture (or literature) and the modern one is artificial if applied to the $17^{\text {th }}$ and $18^{\text {th }}$-century Romanian culture. There is no point in trying to qualify the Romanian culture between 1780 and 1830 as either old or new. It is obviously new, but it also has some archaic elements. The very period 1780-1830 does not mean a total interruption of everything that had been done up to 1730. From a different angle, we may speak about a perfect continuity from 1630 to 1830" (Ivănescu, 2000, p. 633-634).

As it has already been mentioned, the main means of enriching the current vocabulary is the loan. From 1750 up to 1830 the standard language took in numerous neologisms of Greek origin, which was required by "the cultural needs of the age" (Ivănescu, 2000, p. 634). At the same time, linguistic calques, that enrich the scientific and philosophic terminologies, are also recorded, as in the old period, but the frequency of this latter means decreases significantly.

Ivănescu rightly claimed that numerous neologisms are loaned now from Latin and Romance languages. S. Clain and G. Şincai were the first to massively introduce a series of neologisms into Romanian, which they also adapted formally, some of them maintaining up to this day. Other scholars such as Cantemir, Dosoftei, or Milescu had previously been preoccupied with loaning neologisms as well. Clain and other learned people believed that neologisms should be "Romanian-ized". For this purpose, they tried to impose on the Latin words some of the transformations that characterized the popular Latin turning into Romanian process, which shows that these developments were known: Lat. experientia > speriință (or speriență); in P. Maior: distinct > distinpt; in G. Șincai one may find the form plintu 'plant'; in I. Budai-Deleanu one can discover such forms as: Lat. sanctuarium, It. santuario > sfintariu, etc. Not all these transformations were accepted by the Romanian society.

Not only neologisms but also numerous dialectal elements penetrate the standard language now, this process being favoured by the lack of a unique, clear, and unanimously accepted set of norms. The writers in each province were tempted to believe that they could impose linguistic items (even spoken ones) from their region as standard and that they could even elevate their own dialect to the status of writing norm by operating some standardizations. From among them P. Maior and C. Conachi can be illustrative. The former introduced such linguistic items as a mînă 'in hand', se cîștigă 'takes care' (of arms), which were specific to the dialects in Crișana-Maramureș and Transylvania and, thus, may be said to have created a tradition of written language in Transylvania. Costachi Conachi has the merit of having established a tradition of writing in Moldavia. He introduced into the written language a number of specifically Moldavian spoken elements: hojma 'always', mititele 'small', paingul 'the spider'; he also introduced words with palatalised labials into the written tradition: se inghină (present, plural), chirotind, fringhie (replacing the Transylvanian equivalent frimbie), inghie (plural), etc. Conachi also used some neologisms, which he gave a special phonetic adaptation (e.g. plintă). Enriching the written language in Moldavia was continued by G. Asachi. Most linguistic elements introduced by the writers of the time were not personal innovations, but they belonged to the intellectual category, represented particularly by aristocrats (Ivănescu, 2000, p. 636).

Ivănescu states that by 1830 the written language had been influenced significantly more by Greek, Russian, and German than by Latin, French, or Italian. This is why some Romance words entered the Romanian language not directly, but through Greek, Russian, and German-Hungarian. This explains their phonetic aspect and some of their suffixes which were not present in their language of origin: a recomandarisi (borrowed through Greek), a recomăndălui (borrowed through German-Hungarian). After 1830 these forms would be replaced by other forms with no suffix, on I. Heliade Rădulescu's recommendation.

Ivănescu also connects the transition period to the beginnings of the Romanian artistic literature. Previously few literary works had been created: little poetry, through Dosoftei, Miron Costin, and few prose texts, through Dimitrie Cantemir, but they did not succeed in setting up a tradition of artistic 
literature. The poetry that is created now is clumsy (Iannache Văcărescul, Ioan Cantacuzino), yet, some progress can be detected in the texts of C. Conachi and Iancu Văcărescu. However, the lack of tradition of the poetic style caused the language of their poetry to misfit its content ${ }^{5}$ (see Ivănescu, 2000, p. 635).

What distinguishes Ivănescu from other historians of Romanian language is his preoccupation for the written language of the Romanians located Southern of the Danube river, which was generally neglected. Thus, he paid attention to the development of the written language of the Aromanians. Their writing appeared in the $18^{\text {th }}$ century and represented the creation of the bourgeoisie, unlike the Daco-Romanians, whose written language appeared due to the aristocracy. A number of Aromanian scholars, influenced by the Transylvanian ones, started writing in Daco-Romanian with Latin (instead of Greek) letters and introduced innovations in the direction of getting closer to Daco-Romanian writing, their aim being the creation of one written standard for all Romanians. Their activity was, thus, fuelled by a strong nationalist spirit. The theoretician of the unification of the written language of the Aromanians and Daco-Romanians was Gheorghe Constantin Roja, who rejected writing in Greek letters and pleaded for the Latin graphy. As the Aromanians' nationalist tendencies were considered dangerous by the Greeks, the Patriarchy in Constantinopole repressed any manifestations of this kind.

Consequently, in the last phase of his research Ivănescu gives up on the clear-cut separation of the old written language period from the modern one, which was characteristic of the early part of his career, and, instead, prefers searching each period for the archaic elements and the signs of modernity with respect to the written language. Thus, he manages to better show the transition character of the period 1780-1830, by placing all phenomena between "old" and "new", between the obsolete and the innovative.

\section{The modern written language}

1830 is the starting point for what Ivănescu called the second period of the modernization of the Romanian language, which lasts up to the War for Independence (1878), when the contemporary phase of our writing is considered to start. In this period (1830-1878), the transitional character of the standard language is maintained, but what is notable now is the intensification of the modernization of a unitary written norm, while doing away with the elements characteristic of the old writing.

By 1830 the written language had been used particularly by aristocrats. This date marks the beginning of a new phase in the history of our writing in which the written means of expression becomes the communicative instrument of the bourgeoisie, which becomes "the very social organism that supports the written language" (Ivănescu, 2000, p. 647). Mention should be made that Ivănescu does not refer to the entire social category: it is not the merchants and workers but the intellectuals that rose from this category (teachers, judges, administrative clerks, military people, lawyers, doctors, engineers, etc.) who used and supported the new direction of the written language. This intellectual category is much more numerous than before, when it had only consisted of people of clergy and aristocracy. The role of the latter was drastically reduced in the new phase, while the new intellectuals rising from the bourgeoisies assumed the existing norms of writing, with dialectal differences, mostly of lexical nature, and enriched it in the new social and economic conditions. This "take-over" of the standard language by the bourgeoisie resulted in certain changes that led to the modern standard written language. The rise of the bourgeoisie coincides with the beginning of the modernization in the Romanian states and of establishing numerous relationships with the West and Russia.

After 1830, some phonetic, morphologic, and syntactic elements of the old written language, while the spoken language of the bourgeoisie increasingly influenced the written norms. Between 1859 and 1870 the language of the intellectuals rising from the bourgeoisie was imposed as a standard and had its defining features established. It is at this time, too, when the Cyrillic alphabet, characteristic of the old language, was replaced by the Latin one.

5. Budai-Deleanu even deplores in the Prologue to his Țiganiada "the incapacity of language", that is, the insufficient means of expression available to him at the time. 
According to Ivănescu, the creation of the new written language was a "psychological process" (Ivănescu, 2000, p. 656), not a mechanical one. The writers played the leading role: relying on the models of other cultures, they strived greatly to turn the old written language into an adequate instrument for the expression of the modern man's ideas. But the means of achieving these transformations were different from one writer to another and from a province to another. Thus, several language trends manifested in this period, each of them aiming at one common goal: the creation of one unitary writing standard ${ }^{6}$ of the Romanian people. So, they had the same objective, only the means of achieving it were different. Of all the language trends, the ones that imposed were, naturally, those that were based on common sense, i.e., the ones that did not deviate too much from the language of the people. The ways of disseminating the new defining features were greatly diverse: translations, original works, textbooks for schools, legal texts, press, grammar books, and dictionaries. The new linguistic innovations were spread by these means by the scholars with the greatest prestige, to be then assumed by the intellectual masses.

Getting from the old to the new language represents, according to Ivănescu, a complex phenomenon, which includes two processes: the modernization and the unification of the writing norms. Either of them raises a problem: it matters the way in which the modernization process was achieved, that is, how the old writing standard was turned into an adequate instrument that could express modern ideas and simultaneously remained close to the language of the people. As regards the latter process, it is important how the unification of the written language was achieved, given the fact that it had started from several regional written varieties and the attempts at modernization were mainly divergent.

The issue of adapting the written language to the modern contents became acute under the following new conditions: elementary and secondary schools were established in Muntenia and Moldavia, a relatively rich reading audience was created and the lay press appeared. The intellectuals of the time agreed that the starting point could not be a spoken dialect, but the existing written language. Divergent opinions appeared as regards the modifications that had to be brought for the new written language to be created as no none was willing to give up the dialectal features originating in his province.

In Muntenia, the main role in the development of the written language was played by I. Heliade-Rădulescu. In the preface to Gramatica românească (1828), he rejects the previous language and orthography in favour of the uncomfortable forms of some neologisms (verbs ending in -arisesc/-erisesc and -ăluiesc) and some useless elements of the Cyrillic graphy (extra diacritics, spirits, stresses). This is why he tried to reform the Romanian language and orthography. Heliade-Rădulescu used in writing the old written dialect in Muntenia, to which he added some phonetic, morphologic, and lexical changes, proposed by C. Negruzzi, which were generally accepted. He also gave up some archaisms from the previous written language and borrowed elements from the texts written in dialects other than the one in Muntenia.

More precisely, Heliade-Rădulescu introduced some popular spoken elements such as: the form $a$ of the auxiliary of the $3^{\text {rd }}$-person singular compound perfect instead of $a u$, the forms -or and -ar instead of the old etymologic -oriu (from Lat. -orius) and -ariu (from Lat. -arius) in such words as trecător, ajutor, morar, replacing older forms such as trecătoriu, ajutoriu , the form of the relative pronoun without the definite article care instead of carele and carea, pl. carii and carele. He maintained numerous dialectal elements from Muntenia, which were later removed from the written language: the genitive singular $a$ casi 'of the house', the plural nominative urși 'the bears', păste 'over', dă 'of', etc. As regards the treatment of the Latin-Romance neologisms, Heliade pleaded for modifying them, just like the representatives of the Transylvanian School, so that the Latin aspect should be adapted according to the Romanian phonetic develoment: $-t i a>-t ̦ a ̆$, $-\dot{n} n->-i n-$, etc.

The criteria of language enriching applied by Heliade-Rădulescu were: "obeying the type and nature of language" (Ivănescu, 2000, p. 661), by borrowing neologisms from related languages and adapting them, and "the vigour and beauty of language" (Ivănescu, 2000, p. 661-662). For this purpose, he recommended giving up the long and difficult forms, as the plurals in -uri, which he replaced with the ones in $-e$. The

\footnotetext{
${ }^{6}$ Ivănescu uses the phrase national language to refer to the unitary writing standard.
} 
language elaborated by him was only accepted and assumed by the learned bourgeoisie in Muntenia, who also accepted his Italianisms after 1840. However, Heliade-Rădulescu wrongly claimed the unity of the language used in churches and monasteries by only taking into account the Moldavian and Transylvanian ones in the $18^{\text {th }}$ century, similar to those in Muntenia, and disregarding the ones in the $17^{\text {th }}$ century.

In Moldavia, the role of innovator was attributed to G. Asachi. He kept the features of the Moldavian written dialect in the old period, with $\breve{g}$ instead of $j: \breve{g} o c, \breve{g} u d e c$, etc. As for the treatment of neologisms, Asachi followed the model of Russian: he wrote imperie for imperiu (Rus. imperija) and endowed these nouns with the feminine gender. He, too, used some Italianisms such as drit 'right' and forms created by himself as a inainti 'move forward'. Instead of the suffix -itate, which was used by both Transylvanians and Heliade, he used the form -ità, of Italian origin (e.g. cualità).

In Transylvania and Banat, some scholars, among whom T. Cipariu, continued P. Maior's language, while others, like G. Barițiu, followed the writing tradition of the other Transylvanian authors until 1825. Some Latinizing exaggerations were initiated here as well by A. T. Laurian and I. C. Massim, who introduced numerous lexical Latinizing changes, which led to an artificial language.

A no less important role was played by the Moldavian writers in the 1840 generation, the representatives of the national people movement: C. Negruzzi, M. Kogălniceanu, V. Alecsandri, A. Russo, etc. They grouped around the magazines "Dacia literară", "Arhiva românească", then also "Propăşirea". Their language was in some ways different from Asachi's: they used some forms imposed by Asachi (a inainti, studie - feminine noun-, drit 'right', cualità, etc.), but rejected others considered odd, thus getting close to the writing in Muntenia phonetically, morphologically, and lexically.

As the periodic journals in Transylvania used a phonetically similar language to Heliade-Rădulescu's, the Moldavian writers of 1840 thought that it was their duty to do away with some Moldavian elements. Thus, the language of "Dacia literară" (1840) and other publications was very much like Heliade-Rădulescu's.

The writer that initiated the process of the Moldavian writing becoming more similar with the language in Muntenia was C. Negruzzi, under Heliade's influence. In his first text containing features of the language in Muntenia (a translation from Victor's Hugo's Maria Tudor), Negruzzi replaced the forms ending in -toriu, -oriu, - ariu with -tor, -or, -ar, the form au with a for the $3^{\text {rd }}$-person singular auxiliary of the compound perfect, $\hat{i} i$ with $e$ 'is', etc. All these features pertaining to the writing in Muntenia are present in Negruzzi's following texts, too. Furthermore, he convinced the younger authors that were becoming popular at that time (especially M. Kogălniceanu and V. Alecsandri) that the unification of the Romanian written language could only be achieved if the Moldavians were willing to give up some of their dialectal elements in favour of the corresponding forms in Muntenia. As a result, these young authors founded the "Dacia literară" magazine, which aimed among other things at unifying the Romanian written language. This trend was also contested in Moldavia, among whom the best known was G. Săulescu, who polemized with Heliade-Rădulescu on this matter. Although they were the first to give up some of the features of Moldavian writing, the Moldavian authors of "Dacia literară" rejected some specifically Muntenian forms such as şase, șapte, păşaște, jale, slujaşte, etc.

Another author who played an important role in the evolution of the Romanian written language after 1848 was V. Alecsandri. He did not fully adhered to Negruzzi's conception, his getting close to the Muntenian manner of writing being more moderate: by 1875 he had used Moldavia features such as $\breve{g}$ instead of $j$ in words like $\breve{g} o c, \breve{g} u d e c,-s \breve{a}$ for $-s e$ (esă 'goes out'), să 'se' (pronoun), pre 'too', etc. He nevertheless accepted the forms ending in -tor, $-o r,-a r$ and reintroduced in the written language in Moldavia specifically Muntenian forms such as șase, șapte, şarpe, jale, which had been introduced earlier in the $18^{\text {th }}$ century as well. According to Ivănescu, these forms must have been imposed in the unified written language through Alecsandri's works since other Muntenian forms, which he did not use, remained dialectal (păşsaste, slujaşte, etc.).

Between 1860 and 1880 the people in Muntenia, too, gave up some elements of their own written dialect in order to imitate Alecsandri's writing. Thus, a fusion was achieved between the Moldavian and the Muntenian written varieties of 1830-1880, but, however, some differences between the two still 
remained, particularly at the lexical level.

The Moldavian authors that became known after 1859 (Hasdeu and the adherents to Junimena) accepted and imposed some elements of the Muntenian spoken language. Thus, forms such as a inainti, studie, drit, etc. disappeared from Moldavian writing, while other forms like a făcut (singular) instead of au făcut, ei faceau instead of ei fäcea (specific to the old manner of writing). The Moldavian and Transylvanian forms păşseste, slujește were first accepted in Muntenia by Cezar Bolliac, I. Ghica and A. Odobescu. In exchange, the Moldavians at Junimea accepted Muntenian forms like joc, judec, which were already present in Transylvanian writing.

In Transylvania the authors that started writing as early as 1870 to 1880 accepted the written language in Moldavia as it was being elaborated.

The unification of the written language, though not complete, had been achieved up to around 1880, according to Ivănescu. This did not mean removing the Moldavian and Transylvanian norms in favour of the one in Muntenia, which, some researcher argue, must have become the written standard of all Romanians, but it consisted in a mixture (in the sense of a compromise) of the Muntenian and the Moldavian-Transylvanian-Banatian written varieties.

The central tendency within the process of modernization was the Latinization or Romance-ization of vocabulary. This implied introducing in the Romanian writing a massive number of neologisms originating in Latin and other Romance languages and, also, removing Slavic, Greek, and Hungarian elements. This trend was shared by all Romanian intellectuals. Maiorescu, for instance, pleaded for a "reintegration of the Romanian people and culture into the modern world, but, first of all, among the Romance peoples and cultures" (Ivănescu, 2000, p. 672).

Latinization did not only manifest on the lexical level, but also phonetically when it comes to the formal adaptation of neologisms to the specificity of Romanian. Neologisms were usually "phonetically Romanian-ized" (Ivănescu, 2000, p. 677), in the sense of being imposed the phonetic changes they would have been subject to provided they had evolved from Latin. This strategy characterized all Latinists, but was abusively used by Transylvanian authors (Clain, Șincai, I. Budai-Deleanu) so that the words resulted from these transformations were formally identical with those that had evolved from Latin by oral speech, which, however, had a different meaning. Due to the homophony that resulted they were not accepted by the intellectuals after 1880-1900. Some of these forms, resulted from unnecessary adaptations, but done for ideological reasons, were, nevertheless, imposed. An example concerns the Latin neologisms with the

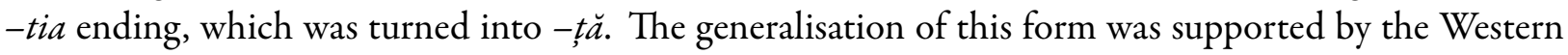
Romance languages using similar endings: It. $-z z a$, Fr. $-c e$, Sp. $-z a$.

Another important feature of modern written language refers to the replacement of the Cyrillic alphabet with the Latin one. This was not done directly, but through some transitional alphabets. I. Heliade-Rădulescu was the one to take up the initiative of introducing such an alphabet; in Gramatică românească (1828), he proposed replacing some Cyrillic letters and removing the stresses and spirits, which were not relevant for the Romanian pronunciation anyway. The orthographic reform proposed by him meant the adaptation of the Cyrillic alphabet to the phonetic system of the Romanian language. The total removal of the Cyrillic alphabet occurred in 1860 in Muntenia and in 1863 in Moldavia.

After the Romanian authors started using the Latin alphabet in the $5^{\text {th }}$ decade, two tendencies appeared, which actually illustrated one trend: etymologism. The former was the Latinist tendency, whose adherents (among whom Cipariu) transcribed those sounds that did not exist in Latin $(/ \breve{a} /, / \hat{\imath} /, / s ̦ /, /$ ț/, /d,/) by means of Latin letters or groups of Latin letters with no diacritic marks. For instance, $/ s, /$ was transcribed through $s$ or $s i, / t ⿱ t /$ through $t$ or $t i$, / $/$ / through $d$ or $d i$. This transcription did not last. The latter tendency was initiated by Heliade-Rădulescu and was the only rational one. It meant a phonetic transcription, but it was not based on one letter - one phoneme correspondence, it transcribed a phoneme through more than one letter, the ones in their original language in combination with diacritic marks. It was, thus, a manner of writing which was phonetic and etymologic at the same time. According to it, /c/ was transcribed as $q u$, when the Latin etymon of the respective word contained the group $q u$, 
the diphthong / ea/ was rendered through é, and /oa/ through $o$, / ke/ and / ki/ through che and chi, respectively. The manner of writing that was imposed was Heliade-Rădulescu's, which was also accepted by such authors as Odobescu, Bolliac, Hasdeu and Alecsandri. In 1869, following numerous debates the Romanian Academic Society voted the etymologic system proposed by those who used diacritic marks to the detriment of Latinists. As early as 1881, the Academy would accept the phonetic orthography, which would mean giving up the Latinizing etymologism. What was imposed was "a kind of etymologism within the boundaries of the Romanian language" (Ivănescu, 2000, p. 690).

The modernization of the Romanian language also implied the development of some new poetic style or "high style". According to Ivănescu it evolved in opposition to the ordinary language, out of the existing synonyms. This is why the poetic style "would vary according to the variations of ordinary language" (Ivănescu, 2000, p. 703), the two of them having parallel evolutions. Thus, if ordinary language enriched significantly, especially in the $18^{\text {th }}$ and $19^{\text {th }}$ centuries, particularly after 1830 , the poetic style, too, developed greatly in the $19^{\text {th }}$ century, when authors wrote numerous poetic texts. An important model for poets was the oral poetic style, which was greatly considered and imitated after 1840, as oral poetry was rediscovered and published by many learned people, among whom V. Alecsandri.

According to Ivănescu, the Romanian poetic style has three basic sources: the old written language, neologisms (as part of the modern written language), and the spoken dialects. Elements of these three sources gained poetic value when they were used in opposition to ordinarily used terms. For instance, when an ordinary word in the old language like slovă was replaced with a neologism like literă 'letter' in ordinary language, the former developed a poetic value through the opposition established with the ordinary term (literă). Of course, the poetic quality was only noticeable from the moderns' perspective. Similarly, other words became poetic: ființă 'being' as opposed to lume 'world' and existență 'existence', neființă as opposed to neant 'nothingness', stih as opposed to vers 'line', crăiasă as opposed to regină 'queen', etc.

As regards the Aromanian culture, Ivănescu stresses a preoccupation and involvement on the part of the Romanians in the Principalities (C. A. Rosetti, D. Bolintineanu, Cezar Bolliac, Cristian Tell, Dimitrie Cazacovici, Dinu Sideri or Iordache Goga) as to the extension of formal education in Romanian for the Aromanians. In the second half of the $19^{\text {th }}$ century, Romanian schools are established in Macedonia for the cultural identity of this Romanian branch to be maintained.

After 1878, a far greater intellectual class is developed on the Daco-Romanian territory owing to the fact that it also included representatives coming from the peasantry, some of whom were also writers (B. Ștefănescu Delavrancea, Al. Vlahuță, I. Creangă, I. Slavici, G. Coșbuc, and so on). This corroborates with the foundation of lots of high schools and the universities in Cluj and Cernăuţi. All these would give the written language greater stability and would lead to the florish of the Romanian culture in the early $20^{\text {th }}$ century, which would reach a peak in the inter-war period. Besides creating highly valuable artistic literature by writers such as M. Eminescu, I. Creangă. I.L. Caragiale, M. Sadoveanu, T. Arghezi, L. Rebreanu, I. Barbu, L. Blaga, or Al. A. Philippide, the development of Romanian culture would also be sustained by the rich scientific activity of such scientists and philosophers as B. Petriceicu Hasdeu, T. Maiorescu, C. Dobrogeanu Gherea, V. Conta, Gr. Tocilescu, A.D. Xenopol, N. Iorga, Alexandru Philippide, C. Rădulescu-Motru, P.P. Negulescu, M. Dragomirescu, G. Ibrăileanu, E. Lovinescu, Ov. Densusianu, G. Ibrăileanu, E. Lovinescu, V. Pârvan, S. Pușcariu, etc.

After 1878, the Romanian written language enters an unprecedented phase of stability ${ }^{7}$ and unity. The only development occurring at that time is of lexical and artistic nature. As it was definitively established, the written language is no longer subject to meaningless changes of its elements; instead, it only changes for the purpose of expressing new notions and achieving new artistic values. The lexical development was connected then to the progress in the fields of material and spiritual cultures of the Romanian people.

A so-called "intellectual style" (Ivănescu, 2000, p. 734) was created in this period, characterized by

\footnotetext{
${ }^{7}$ In Ivănescu's view, the development of a standard language includes a formation period, followed by a phase of stability.
} 
a series of neologisms borrowed from Western languages. They were especially known and used by intellectuals, who accepted them, although the Romanian language had already had terms for naming the same realities: benign, cotidian, decență, depravat, depravare, impecabil, impertinent, rural, rustic, urban, etc. They are synonymous with well-known terms, used ordinarily: blind, zilnic, cuviincios or politicos, cuviințăa, stricat or desfrînat, fără păcate or fără cusururi, obraznic, țărănesc or sătesc, orăşsenesc, etc. Thus, "the standard language underwent a halving process" (Ivănescu, 2000, p. 703), similar to that in the age of the Latinists and Italienists, only this time the new terms no longer tend to replace the already existent ones, they merely endow the expression with a note of elegance and distinction.

As regards its place against the European background, Ivănescu believes that the Romanian written language may be considered similar to the other Romance languages owing to the fact that during its development it borrowed a lot of neologisms from Latin out of the need to express specific intellectual ideas. As it developed later than its European counterparts, our written language rebuilt its Latin vocabulary, which it had lost along its history as it had been replaced with non-Latin items. What distinguishes the Romanian written language from the Slavic languages, German, or Hungarian is the great percentage of neologisms based on which the former developed its lexicon, particularly in the modern phase, unlike the other languages, which were enriched predominantly by means of calque.

\section{Conclusions}

Ivănescu is a scholar that remains consistent with his own principles of studying language diachrony. His theoretical ideas on linguistic development and the way in which it should be approached are to be found in the applied analysis sections of his writings.

Thus, Ivănescu pleaded for the separation of the study of spoken language from the description of the history of written language. This separation, imposed by the conviction that the two varieties (spoken and written) of any national language are fundamentally distinct and are, consequently, acted upon by different factors is theorised in his diachronic writings. Ivănescu is, thus, materialist, idealist, and sociologist, when studying the history of spoken languages, and idealist when dealing with the evolution of written languages.

Under these circumstances, an element of novelty which, we believe, elevates Ivănescu's History above other linguistic histories is connected to its relying on a number of strong principles, which gives the presented material increased clarity and considerably facilitates its understanding by readers. We would even argue that due to this organization, his work is highly accessible even to those less initiated without this implying the loss (or diminishing) of the scientific discourse quality of the text.

As regards the history of our written language, its beginnings are connected by Ivănescu to the $15^{\text {th }}$ century along with the first written texts in Romanian, namely, the rhotacizing texts. The history of the Romanian written language is divided into two phases: an old one and a modern one, but what distinguishes Ivănescu's theory is the idea of written dialects in the old period, i.e., the fact that the written language had been regionally fragmented up to the $19^{\text {th }}$ century. By pleading for this, the Iassian scholar went against the idea of a unitary written language in the old period, which was upheld by other linguists (especially by those in Bucharest). The scientist has, thus, the merit of having established the dialectal perspective for the research of the written language, it having previously been applied to the spoken language.

The value of Ivănescu's conception also lies in its complexity which is due to it being supported by ideas coming from several linguistic doctrines. We stress that Ivănescu did not merely adopted some ideas and brought them together; instead, he reinterpreted, reformulated, and articulated them into an original linguistic theory. Of no less importance is the fact that the Iassian scholar did not confine his research to a strictly linguistic survey, but he included in his research lots of information from several scientific fields (history, sociology, anthropology), which gives his works an interdisciplinary, erudite, and even encyclopædic dimension. 


\section{Bibliography}

Coseriu, E. (1977). Sincronie, diacronie și istorie, translated by Nicolae Saramandu, Editura Enciclopedică, București.

Coseriu, E. (2000). Limba funcțională, in vol. Lecții de lingvistică generală, Editura ARC, Chișinău, p. 263.

Gheție, I. (1975). Baza dialectală a românei literare, Editura Academiei Republicii Socialiste România, București.

Ivănescu, G. (1946-1947). Istoria limbii române în lumina materialismului dialectic, in "Buletinul Institutului de Filologie Romînă“, vol. XIII-XIV, Iași, p. 3-48.

Ivănescu, G. (1947). Problemele capitale ale vechii române literare, in "Buletinul Institutului de Filologie Romînă”, vol. XI-XII, Iași, p. 1-412.

Ivănescu, G. (1988). Studii de istorie a limbii române literare, Junimea, Iași, p. IX.

Ivănescu, G. (2000). Istoria limbii române, Junimea, Iași.

Ivănescu, G. ([s.a.]). Istoria graiurilor populare și istoria limbilor literare, unpublished text, to be found at the Library of the Iassy subsidiary of Romanian Academy, the Ivănescu collection, p. 11.

Saussure, Ferdinand de (1998). Curs de lingvistică generală, Polirom, Iași. 